\title{
DANIEL'S PRACTICE: THE DAILY ROUND OF GODLY WOMEN IN SEVENTEENTH-CENTURY ENGLAND
}

\author{
by ANNE LAURENCE
}

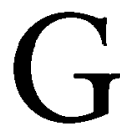

ODLY women from noble, gentry, mercantile, and clerical families were much commemorated at their deaths in funeral sermons. Apart from preaching on a suitable text, ministers commonly gave an account of the life of the deceased, describing, amongst other things, how she passed her time. Godly lives from sermons for men outlined the course of their careers, stressing their public activities, the manner in which they took religion out into the world and engaged with worldly matters; those for women followed a formula describing the deceased's childhood, virtuous education, marriage, performance as wife, mother, mistress of servants, hospitality (especially if the woman was the wife of a minister), and charitable work, and enumerated her merits in these roles. Instead of recounting the events of their whole lives, ministers dwelt upon the women's daily routine of pious practices, with variations for the Sabbath or days on which they took communion. The convention of de mortuis nil nisi bonum was strictly observed, but the edificatory nature of the life was also an important element in the telling of it. Sometimes sermon titles acknowledged this, otherwise they referred to the good death of the deceased or, if they were published to improve the career prospects of the preacher, they referred to the text upon which he had preached.

Women were praised for following Daniel's practice, the practice for which he was thrown into the lions' den. This was to kneel upon his knees, three times a day, and pray and give thanks before his God. ${ }^{1}$ In the early years of the seventeenth century, Mrs Mary Gunter, companion to Lettice, Countess of Leicester, 'resolved upon Daniels Practice'. 'Besides Family duties, which were performed twice every day, by the Chaplain ... And besides the private Prayers which she daily read in her Ladies Bed-Chamber, she was thrice on her Knees every day before God in secret.'2 Lady Elizabeth Langham's 'constant

1 Dan. 6.10.

2 Samuel Clarke, The Lives of Sundry Eminent Persons in this Later Age (London, 1683), part 2, p. I 37 . For a discussion of this work, see Jacqueline Eales, "Samuel Clarke and the "Lives" of godly women in seventeenth-century England', $S C H, 27$ (1990), pp. 265-76. 
retirements' for her devotions in the I660s 'were answerable to Daniels thrice a day'?

Others went further and followed David's practice, 'Seven times a day do I praise thee because of thy righteous judgements.' Elizabeth Langham, from three times a day, 'more than doubled that proportion even to David's seven times a Day' after the death of her much-loved sister-in-law. ${ }^{5}$ Thomas Ken, preaching in I682 at the funeral of Lady Margaret Mainard, described her devotions as following David's example 'as far as her bodily Infirmities and necessary Avocations would permit'. Not surprisingly, he also commented that 'her Oratory was the place, where she principally resided, and where she was most at home.' ${ }^{6}$ The royalist Anne Halket 'divided the 24 hours into three parts, allocating five for Devotion, ten for necessary refreshment, nine for Business'. The five hours dedicated to devotion were from 5 to 7 a.m., I to 2 p. m., 6 to 7 p. m., and 9 to Io p. m. ${ }^{7}$ Mrs Eleanor Murden supposedly spent 'half her time in Praying and Reading, her circumstances allowing her leisure for it'. ${ }^{8}$

While funeral sermons naturally tend to stress the virtues of the deceased rather than their imperfections, diaries and autobiographies are more revealing about the success of efforts to observe the discipline of the godly timetable. As explicit exercises in spiritual accounting, they required the acknowledgement of personal failings. The Countess of Warwick was said to pass two hours a day in Meditation and Conversing with the Invisible World'. ${ }^{9}$ However, she confessed in her diary that, especially when she was in London, she found the religious life difficult. ${ }^{10}$

The terms in which female godliness and the devout management of time are described have little to do with their religious or political allegiances. Margaret Houghton was the widow of a royalist M.P., but Isaac Ambrose, who preached her funeral sermon and whose prefer-

3 Clarke, Lives, 2, p. 200.

4 Ps II9.164.

5 Clarke, Lives, 2, p. 200.

6 Thomas Ken, $A$ Sermon Preached at the Funeral of the Right Honourable Lady Margaret Mainard (London, I682), p. 24.

7 The Life of the Lady Halket (Edinburgh, 1701), p. 55.

8 Thomas Reynolds, A Funeral Sermon upon the Death of Mrs Eleanor Murden (London, 1713), p. 25.

9 Anthony Walker, Leez Lachrymans sive Comitis Warwici Justa (London, 1673), Epistle Dedicatory.

10 Memoir of Lady Warwick: also her Diary, Religious Tract Society (London, I847), p. 90. 
ment to the vicarage of Preston she had assisted in I649, was a wellknown Presbytcrian who lost his living in 1662. Lady Capel was the widow of Arthur Lord Capel, who had objected to ship money but had refused to rebel against the King. Elizabeth Langham was the wife of a royalist gentleman with a recent mercantile fortune, but more significantly she was the daughter of the Earl of Huntingdon, a royalist family but with a strong tradition of Puritan godliness. The Countess of Warwick was the wife of a strongly parliamentarian and Puritan man, and the daughter of the equivocally royalist Earl of Cork.

Their devotional regimes, even if imperfectly observed, imposed a considerable discipline on these women's lives, and one which biographers did not see as competing with their duties as wives and mothers. "The perfection of a Lady that has a great Family, consists not in being all day upon her knees, but in dividing her time so well, as to set apart a proportion for prayers, and the rest for the affairs of her Family.'11

However, time management was an important matter, and conduct manuals and manuals of personal devotion, virtually always written by men, gave advice on organizing the day around religious devotions. It is common to find authors emphasising the need for different kinds of religious activity - family prayers, private reading, meditation, and study - but being noncommittal about the actual hours at which these activities should take place. The Puritan Isaac Ambrose believed that 'No time can be prescribed to all men; ... it is enough that we set apart that time wherein we are aptest for that service. ${ }^{12}$ The godly had a duty not only to God but to others. The nonconformist Samuel Slater advised that private prayer had to take its place alongside other duties. 'Know, $\mathrm{O}$ man, thou sinnest if thou art in thy Closet, when it is thy duty to be in thy Shop; or thou, $\mathrm{O}$ woman, when thou oughtest to be employed about the affairs of thy Family; and thou, O Servant, when thou shouldest be doing thy Master's or thy Mistris's business.'13

Theophilus Polwheile, another Puritan divine, giving Choice Directions How to Serve God, advised adaptability. 'Let nothing interpose [between you and your private prayer] unless some special business

\footnotetext{
1 Edward Panton, Speculum Juventutis: or, a True Mirror; Where Errors in Breeding Noble and Generous Youth, with the Miseries and Mischiefs that Normally Attend It, are Clearly Made Manifest (London, I671), p. 278.

12 Isaac Ambrose, 'Of the Nature and Kinds of Meditation', in The Compleat Works of that Eminent Minister of Gods Word Mr Isaac Ambrose (London, I674), p. I82.

13 Samuel Slater, $A$ Discourse of Closet (or Secret) Prayer (London, 1691), p. 173.
} 
accidentally come to be considered of', and if at such times there was 'occasion to speak (as having a bed-fellow, or any other company with you) let your discourses be suitable'. ${ }^{14}$ Likewise, when going to bed he gave advice on meditating while undressing: 'Let your speeches (if there be company) be spiritual.' ${ }^{15}$ But he also advised his readers not to leave work undone in order to have time for religious duties, but rather 'to dispatch your work that you may have time'.16

This reticence is in marked contrast to the manuals of huswifery which showed no hesitation in laying down most detailed timetables for the performance of household tasks. Elizabeth Burnet, third wife of the bishop, combined the advice of a devotional manual with more practical advice in managing a household and offered such stern injunctions as, 'Allow no more Time for sleep than Health requires. ... Six or Seven Hours is enough for most Constitutions. ${ }^{17}$ But she was refreshingly direct about the difficulties, 'if needless Scrupulosity is indulged, it will become tedious, and more superstitious than profitable.' 18

Different regimes were considered to be appropriate to different orders of people. Polwheile believed that servants should perform their religious duties in their own time, not their masters', for 'God does not allow that'. ${ }^{19}$ Married and single women were expected to conform to Paul's advice that 'The unmarried woman careth for the things of the Lord, that she may be holy in both body and in spirit: but she that is married careth for the things of the world, how she may please her husband.'20 This belief gave rise to comment that Elizabeth Langham, at her marriage, 'abated not of her Devotion, and

14 Theophilus Polwheile, Choice Directions How to Serve God, every Working and every Lords Day (London, 1667), p. 79.

15 Ibid., p. 106.

16 Ibid., p. 93. Robert Russell, preaching on the duty of prayer, drew a nice distinction between work and non-work: 'for People to go on and pour out their Souls to God in Secret, confess their own particular Sins and daily Infirmities, bemoaning their Case to God, bewailing their inbred Corruption, lamenting over a hard Heart, a blind Mind, a dead and dull Spirit, a hearty begging for Pardon, for Deliverance from Sin, for Power against Corruption, for Strength against the evil Lusting of the Flesh, Begging for Grace and a new Nature, and a new Life: now this Work, together with frequent Meditation, and SelfExamination, these Duties the Devil opposeth with all his Might': Robert Russell, 'The Saint's Duty and Exercise', in Seven Sermons, 29th edn (London, 1719), pp. 59-60.

17 Mrs Burnet, $A$ Method of Devotion, 2nd edn (London, 1709), p. 3.

18 Ibid., 26.

19 Polwheile, Choice Directions, p. 93.

20 I Cor. 7.34. 
thereby rendered herself a singular instance of exception, to the difference which the Apostle St Paul puts between a Wife and a Virgin.'21 Margaret Mainard both 'retained her accustomed devotion which she practis'd when a Virgin', and successfully 'united Martha and Mary together, took a due care of all her domestick Affairs, and manag'd them with a wise frugality, with a constant deference, to God's merciful providence.'22

By the later seventeenth century such religious devotion was seen as primarily a female activity. The poet laureate Nahum Tate wrote in I693, that 'it must be confessed, and ascribed almost wholly to the female sex, that religion at this day is anything more than a name... We are too busy for contemplation, and leave it to the women as having more leisure to observe the punctilios in religion. ${ }^{23}$ For men, time spent on private devotion was secondary to their main occupation. Sir George Dalston, who died in 1657 , gave himself to religion and devotion having divested himself of secular employment, but only after forty years as an M.P. ${ }^{24}$ The young John Harington, who died at the age of twenty-two, was exceptional in leading a life disciplined by godly exercises. Needing only six hours sleep, he would often wake at four or five in the morning, read a chapter of Scripture, pray with his servants in his chamber, spend an hour reading some holy treatise such as Calvin's Institutes, share a psalm, chapter, and prayer with his family before dinner and supper, and conclude the day with prayers after supper. In addition, there was private prayer in his closet, three or four hours study and meditation on a sermon after dinner, and writing his diary after the prayers after supper. Before finally going to sleep someone in his chamber read him a couple of chapters of the Bible. ${ }^{25}$ The account of his life inspired the young Elizabeth Langham to her regime of pious practices. ${ }^{26}$

A life of religious discipline might be regarded as work, occupying women's days with what could be a punishing timetable. This 'work'

21 Clarke, Lives, 2, p. 200.

22 Ken, Sermon, p. 35.

23 Nahum Tate, $A$ Present for the Ladies, being an Historical Account of Several Illustrious Persons of the Female Sex, and edn (London, I693), pp. 84-5.

${ }_{24}$ J[eremy] T[aylor], D.D., A Sermon Preached at the Funerall of that Worthy Knight Sir George Dalston (London, I658), p. 33.

${ }_{25}$ Samuel Clarke, The Marrow of Ecclesiastical History, The Second Part (London, 1775), pp. $59-60$.

26 Simon Ford, A Christian's Acquiescence (London, I665), p. I 16. 
was contrasted with leisure, on the one hand, and idleness on the other. Some women's devotions amounted to work, in the sense of being their principal employment. The terms 'task' and 'holy Work' were used of Elizabeth Langham's activities. ${ }^{27}$ It was said of Lady Capel that 'prayer [was] the first work she went in hand with every morning. ${ }^{28}$ Elizabeth Wilkinson was said to be 'much busied in prayer, meditation and selfe-examination'.29 Lady Anne Waller, wife of the parliamentary general, was, according to the Puritan divine Edmund Calamy, 'one who made Religion her business, not (as some Ladies do) her Idle hour, but her daily labour. ${ }^{30}$ Margaret Mainard's 'chief employment, was Prayer, and Praise'.31

A favourite text was Ephesians 5.I6: 'Redeeming the time because the days are evil'. Not wasting time was an essential part of the discipline of the godly life. Isaac Ambrose's sermon on this text for Lady Margaret Houghton in $1657 / 8$ claimed that 'Well she had learnt that idleness was the rust and canker of the soul, the Devils cushion, pillow, chief reposal.'32 Lady Capel was 'a zealous abhorrer and hater of idleness' and it was said of Elizabeth Langham that she took care to spend the time when she was not at prayer or religious duties in profitable converse' and that she

did buy Time out ... of the Hands of those Wasters of precious Minutes, which buy it all up, even from the most Religious imployments, to lavish it out in Pass-times and Recreations ... she never allowed herself to see any maskes, Interludes or Plays; or to play at Cards or the like Games. ${ }^{33}$

The Countess of Warwick was said by the preacher of her funeral sermon in 1678 not to play any games, judging them 'great wasters of

27 Clarke, Lives, 2, pp. 200-I.

${ }^{28}$ Edmund Barker, $A$ Sermon Preached at the Funerall of the Right Honourable and Most Excellent Lady, the Lady Elizabeth Capell, Dowager, together with some Brief Memorialls of her Most Worthy Life and Death (London, $166 \mathrm{I}$ ), p. 34.

29 Edmund Staunton, $A$ Sermon Preacht at Great Milton in the County of Oxford Decemb: 9 1654 at the Funerall of that Eminent Servant of Jesus Christ Mrs Elizabeth Wilkinson, late Wife to Dr Henry Wilkinson, Principall of Magdalen Hall; Whereunto is added a Narrative of her Godly Life and Death (Oxford, 1659), p. 24 -

${ }^{30}$ Edmund Calamy, The Happinesse of Those who Sleep in Jesus (London, I662), p. 28.

31 Ken, Sermon, p. 24.

32 Isaac Ambrose, 'Redeeming the time. A sermon preached at Preston in Lancs January $4^{\text {th }}$ I657', in Ambrose, Works, p. I4.

${ }^{33}$ Barker, Sermon, p. 37; Clarke, Lives, 2, p. 200. 
precious time, of which she was always very thrifty'. ${ }^{34}$ In her autobiography she referred to her conversion resulting in her days being 'almost quite taken up in reading, meditation and prayer, being then very solicitous to redeem my former misspent time'. ${ }^{35} \mathrm{Her}$ experience of conversion gave her 'inexpressible comfort', 'which did make me to hate and disrelish all my former vain and idle pleasures'. ${ }^{36}$

Religious discipline required every minute of the day to be filled. One of Lady Capel's virtues was that she was 'a strict accountant' of time, 'even to small parcels: beshrewing and grutching [grudging] every hour, which was otherwise spent, than either in the actual service of her God, or at least in some proportion and tendence thereunto'.37 Lady Alice Lucy used every available opportunity to offer prayer and 'never removed out of one Room into an other, but she used some short Ejaculations, with lifting up her Eyes and hands to God'.38

For some women, private religious activities expanded to fill what they perceived as the amount of leisure available to them. Elizabeth Burnet's biographer reported that 'when she would divert herself with Work [that is, needlework], she had generally some Persons to read to her. ${ }^{39}$ She herself used the word 'leisure' to indicate periods of time when extra devotional activities might be added, suggesting, for example, that those who had the leisure should reflect on the virtues they found particularly difficult.

Even leisure needed to be occupied constructively. Margaret, Duchess of Beaufort, daughter of Lady Capel, was known for spending that time 'that many other ladies devote to the tiresome pleasures of the town ... virtuously and busily employed in her garden. . . [H]er servants assured us, that excepting the times of her devotions, at which she was a constant attendant, gardening took up two thirds of her time. ${ }^{40}$ Elizabeth Burnet's biographer refers to her spending much of

34 Anthony Walker, Eureka, Eureka. The Virtwous Woman Found, Her Loss Bewailed (London, I678), p. 58 .

35 Mary Rich, Countess of Warwick, Autobiography, ed. T. Crofton Croker, Percy Society, 22 (London, I848), p. 23.

36 Ibid., p. 22.

37 Barker, Sermon, p. 37

38 Clarke, Lives, 2, p. 14 I (ejaculation meaning short extempore prayer).

39 Burnet, Method of Devotion, p. vii.

40 Stepher Switzer, The Nobleman, Gentleman, and Gardener's Recreation (London, I7 I5), p. 54 . 
her time at her devotions and in reading when she lived in the country 'where she had much leisure'. After the death of her first husband, she 'had more Time and Leisure' to spend on them. ${ }^{41}$

The Duchess of Beaufort and Mrs Burnet, wife of the bishop, were wealthy and well-connected women. Indeed, almost all the examples quoted hitherto are of women of gentry or noble status, from prosperous if not wealthy circumstances which allowed them, and other women like them, to carry out their schedules of prayer and meditation. Two women of more modest circumstances, both wives of ministers, provide counter examples; they could scarcely afford to pray three times a day, let alone seven. Katherine Clarke, after her religious duties and household tasks, 'at leisure times imployed her self in knitting stockings for her self and grand-children'. ${ }^{42}$ Another clergyman's wife, Mrs Crook, evidently sacrificed her own leisure to her husband's, for she was 'carefull, to free and ease him of all emergent occasions, avocations, and businesses of ordinary concernment, that so he might with the more freedom follow ... his divine imployments, and enjoy himself, and friends in his necessary relaxations' ${ }^{43}$

Leisure was something to be used profitably and idleness was to be avoided. Lady Capel's chaplain inveighed against idleness as

a vice, grown of late years the common fashion and distinction, of too many of her [Lady Capel's] rank and quality; who, because the plenty and abundance of their estates, do advance them beyond the necessity of working for a livelihood, do therefore look upon themselves as priviledged and mark't out unto a life of Idleness; not considering that God Almighty, who hath given Ladies hands as well as others, doth also expect work and action from them (in proportion to their rank and quality) as much as from any people. ${ }^{44}$

His patron was herself

careful to be continually busying her self about some good employment or other... so in case her spiritual enemy should

41 Burnet, Method of Devotion, pp. vii, $\mathrm{x}$.

42 Samuel Clarke, $A$ Looking-Glass for Good Women to Dress Themselves by (London, 1677), p. 26.

43 Samuel Clarke, $A$ Collection of the Lives of Ten Eminent Divines (London, r662), p. 32.

44 Barker, Sermon, p. 37. 
come suddenly thrusting upon her at any time with his temptations, she might have her answer ready, viz. That she had other work in hand and was not at leisure now to attend him. ${ }^{45}$

But for women of high social status, employment was not necessarily much more than the practice of ladylike accomplishments. Anne Halket declared that her childhood lessons in writing, speaking French, playing the lute and virginals, dancing, and needlework, showed that she was 'not brought up to an idle life'. ${ }^{46}$ Idleness was addressed in the conduct literature with advice to allow 'no temptation [to] find opportunity to fix upon your wandering thoughts'. ${ }^{77}$

Idleness was equated with pointless amusements and with spending excessive time on unworthy ends. Dressing in the morning might provide the occasion for wasting time. Elizabeth Burnet advised, 'Lose not the Morning, by being too long in eating your Breakfast and Dressing. ${ }^{38}$ But it would be wrong to think that personal appearance was not of concern to the godly. They decried vanity and the mutability of fashion; nevertheless, a comely countenance and dress appropriate to the wearer's status were very important, and time spent on it was significant. Susanna, Countess of Suffolk, who died at the age of twenty-two in 1649 , was said to have 'the least affection' for 'her Attire and Dressing' for herself 'but only for those who were related to her, that she might not seem mean or unworthy [of] their allyance or affections'. ${ }^{49}$

Dressing was plainly a process that took a substantial amount of time even for those who were not particularly concerned with their appearance, so it provided the occasion for reflection. Elizabeth Burnet counselled that 'While Dressing, at least before engaging in worldly Business or Study, employ your Thoughts on such Reflections as these: If any Sin has been committed since your last Examination, if you have indulged Sloth beyond the Rules of Health, or the like'. ${ }^{50}$ Such considerations were not restricted to the manuals. Elizabeth

45 Ibid., p. $3^{8 .}$

46 John Loftus, ed., Memoirs of Anne, Lady Halkett and Ann, Lady Fanshawe (Oxford, 1989), p. 10.

47 The Whole Duty of a Woman: or a Guide to the Female Sex from the Age of Sixteen to Sixty

.. Written by a Lady, and edn (London, I696), p. 3.

48 Burnet, Method of Devotion, p. 100.

49 Clarke, Lives, 2, p. 212.

50 Burnet, Method of Devotion, p. 7. 
Langham's memorialist was at pains to explain that, though she spent so long on meditation in her closet, she did not neglect her appearance, bestowing on it 'so much time and pains (after the necessary concerns of her Soul) as decency required, tho haply not so much as curiosity . . . would have called for'. ${ }^{51}$ The Countess of Warwick's diary suggests that she spent as little time as possible in dressing, while Lady Lane had her children read passages from the Scriptures to her while she was dressing. ${ }^{52}$

By the later seventeenth century advocating and, indeed, holding up as a good example a life dedicated to religious observance carried less weight, perhaps because of fears of religious enthusiasm. The preacher of Lady Newland's funeral sermon in I690 acknowledged that it was remarkable that, though she spent two hours in the morning at prayer and at least another hour before retiring at night, 'this severe and abstracted kind of Life, which she led, and which in others is too commonly attended with some very bad consequents, with Moroseness and Peevishness, Pride and Censoriousness ... in her ... produc'd quite the contrary. ${ }^{53}$ The Countess of Orford, who died in I702, was said to have been 'ever constant to the prayers, service and sacraments of the church, at which her behaviour was devout and solemn, decent, natural and unaffected, and showed she was not acted by unaccountable fits and transports of devotion'.54 Elizabeth Burnet advised moderation in devotional activity, but perhaps more from an apprehension that setting one's sights lower might in the end achieve more than from fear of enthusiasm. She advised that the portions of Scripture read as a basis for meditation should not be long, and that study should be governed by whether 'your Inclinations dispose you, and your outward Circumstances admit much Reading. ${ }^{55}$ However, she warned that "tis a Sin and shame to give hours to dressing and to think half an Hour long in Prayer. ${ }^{56}$

There was little to choose between high Anglican and Puritan regimes, and advice given to Catholics was very similar to that of Protestant manuals. There is the same stress on organizing time,

51 Clarke, Lives, 2, p. 200.

52 Memoir of Lady Warwick, pp. 73, 74, 81; Nathaniel Taylor, A Funeral Sermon Occasioned by the Death of Lady Lane (London, 1699), p. $3^{2}$.

${ }^{53} \mathrm{John}$ Scott, $A$ Sermon Preached at the Funeral of the Lady Newland (London, I690), p. I6.

54 Samuel Barker, $A$ Sermon Preach'd at the Funeral of the Right Honourable the Countess of Orford (London, I 702), p. 6.

55 Burnet, Method of Devotion, pp. 80, 95 .

56 Ibid., p. I04. 
meditating, and examining one's conscience. ${ }^{57}$ Likewise, Catholic vies édifiantes served a very similar function to the lives of Protestant women, as we may see in the life of Margaret Clitherow, for example. ${ }^{58}$

It is clear that those women with the time, money, and inclination took with great seriousness religious injunctions to use their time profitably. However, the most voluminous source for their conduct, the funeral sermon, is not easy to construe. Funeral sermons were explicitly dedicated to praising the deceased; in some of them no hyperbole is spared. They also had an exemplary function, providing a model for Christian life. The details of the deceased's life were set out, with an account of her parents, marriage, and children, and of her virtues as mistress of servants and benefactor, then her daily round from rising in the morning to going to bed at night. The auditor or reader might be supposed to wish to model her life on this example.

This formula had a further function. It is a kind of trope, a trope which is used both for the time of day and the place in the house (from which it ought perhaps to be called a topos rather than a trope). It offered an aide-memoire for what was required of the good Christian. Such timetables imposed discipline and order on religious life, ensuring that the duties which had to be performed got done. The location in time and place served as a reminder of the kind of religious activity that was required. But this was a discipline for wealthy and leisured women. These women were praiseworthy for passing their days diligently and not in frivolous activities. Few women had a funeral sermon preached extolling their virtues as wage-earners. So the discipline of Daniel's practice provided occupation for the leisured class rather than a pathway to heaven for the righteous.

\section{The Open University}

57 A Daily Exercise, and Devotions, for the Young Ladies, and Gentlewomen Pensioners at the Monastery of the English Canonesses Regular of the Holy Order of S. Augustin, at Bruges (Douai, 1712), pp. 5-6, 40,43.

58 Quoted in Claire Cross, 'The religious life of women in sixteenth-century Yorkshire', SCH, 27 (1990), pp. 318-19. 